\title{
The Activity of Nimba Leaves (Azadirachta Indica A. Juss.) Extract Insecticide as Vegetative Pesticide on Rice Weevil (Sitophilus Oryzae L.) (Coleoptera: Curculionidae)
}

\author{
I Wayan Suanda ${ }^{1^{*}}$ and Ni Made Delly Resiani ${ }^{2}$ \\ ${ }^{1}$ Prodi Pendidikan Biologi FPMIPA IKIP PGRI Bali, Jl. Seroja No. 50 Tonja-Denpasar Utara, Bali \\ ${ }^{2}$ Balai Pengkajian Teknologi Pertanian Bali, Jl. By Pass Ngurah Rai Pesanggaran-Denpasar Selatan, Bali \\ * Email: suandawayan65@gmail.com
}

\begin{abstract}
The purpose of the research regarding The Activity of Nimba Leaves (Azadirachta Indica A. Juss.) Extract as Vegetative Pesticide on Rice Weevil (Sitophilus Oryzae L.) is to identify the characteristics of contact poison, pesticide, and antifeedan from Nimba leaves extract on rice weevil (S. oryzae L.). The research is conducted in the biology laboratory Faculty of MIPA University of Udayana. The period of the research is from April to August 2017, using the complete random framework with 6 concentration tests $(10$ ppm, 100 ppm, 1000 ppm, 10000 ppm, 100000 ppm concentration, and control using methanol pro analysis (PA) solvent). Each test is repeated 4 times. The data is analyzed using Analysis of Variance (ANOVA) and if there is a significant difference $(P<0.05)$ it is followed by Duncan test to identify the difference between the different tests. The data is quantified using SPSS for windows release 12.5 the year 2003. The result indicates that the extract of Nimba leaves A. indica A. Juss. is behaving more as an antifeedan at an optimum concentration of $1000 \mathrm{pm}$ during the observation 48 hours after the test. The crude extract of Nimba leaves at an optimum concentration of 1000 ppm and a maximum of 10000 ppm, during the observation 36 hours after the application, is leaning towards behaving as a contact poison to the S. oryzae $L$.
\end{abstract}

Keywords: Azadirachta indica A. Juss., Sitophilus oryzae L, antifeedan.

\section{Introduction}

Rice is the main staple food for Indonesia and the world. The demand for rice in Indonesia is increasing every year parallel with the increasing of the population. The significant increase in population each year causes an increase in the demand for rice. Rice is still a strategic commodity in the economy and the national food security, therefore making it the main revitalization for farming in the future. The competitiveness of rice compared to other commodities is descending, however, efforts to develop and increase the national rice production is necessary with the main target is to achieve rice sufficiency and also the prosperity of the farmer. There are several difficulties in achieving the target, one of which is the factor of incorrect handling post-harvest period. The process of storing the rice is one of the most important chains in the supply chain of post-harvest [1].

Storing rice is also important as it becomes the food supply to overcome in times of drought and flood that cause crop failure. During the storing process, rice undergoes a degradation of quality and quantity [2]. The degradation during the storing process may happen due to the pest attack. Storing rice is important to maintain the continuity of rice supply and to fulfill the food supply for the people of Indonesia, started from the supply on the household level. The availability of rice is a necessity at times of extreme conditions, such as prolonged dry season, crop failure, flood, and other natural disasters as anticipation of food shortage. Therefore every household must be aware of this food shortage condition by keep supplying rice or fulfilling food security. Regulation Number 18 the Year 2012 regarding Food, Article 1 point 4 stated that "Food Security is a condition of fulfillment of food from country to individual level, which is reflected by the 
availability of sufficient food, both in quantity and quality, secure, vary, nutritious, prevalent, and affordable as well as not in contradict to religion, belief, and the local custom, to maintain a healthy life, be active and productive in a continuity."

Post-harvest storing is a strategic chain to achieve national rice security. [3] stated that postharvest product is part of crops which are harvested for various purposes mainly to give added value and profit for farmers or consumers. It is also stated that products in this storing are inseparable from organic crop pests especially the insect type. [2] added that the storing process in the storage reduces the quantity and the quality of the rice by 5-20\%. The long period of storing rice is prone to be damaged by rice weevil, therefore the rice that is going to be cooked will be damaged and contain this insect. [4] stated that the continued attack of rice weevil could cause a declining quality and contamination on a food product, therefore rendering it inedible. The damage to the rice which is caused during the storing includes both quantity and quality damage. The cause of the damage is mostly due to the attack of the post-harvest pests [5].

The post-harvest pest that attacks the rice crops in Indonesia includes Sitophylus oryzae, $S$. zeamais, Corcyra cephalonica, Plodia interpunctella, and Oryzaephilus surinamensis[2]. S. oryzae L. is a primary insect pest that is a polyfag, attacks whole crops that damage rice, sorghum, wheat, and corn with destruction level up to 5-20\% [6]. The damage in a food product that happens during the storing process is physical damage (color, solidity, the thickness of grain skin, and size of the seed), chemical damage, mechanical damage, biological damage and microbiological damage which cause the decline of the quality and the quantity of harvest crop [7], [8], [9].

There are numerous ways in containing rice weevil ( $S$. oryzae L.), one of which is to mix chemical substances such as Chlorine to the rice. The issue of environmental pollution and the negative impact on health have become the fundamentals of global policy regarding synthetic pesticide use restriction in which its manifestation can be seen by the more restrictive regulation which includes ecolabelling. One of the potential crop to become a vegetative pesticide is Nimba (Azadirachta indica A. Juss.), which contains azadirachtin that is accumulated on the leaves and specifically on in the seed [7]. The biological activity of Nimba is caused by the bioactive substance contained which is a part of limonoid (triterpenoid). There are nine limonoid substances which have been identified, some of them are azadirachtin, meliantriol, salanin, nimbin, and nimbidin [10].

The use of environmentally friendly pesticides (vegetative pesticide) is still unfamiliar among people, which is caused by the lack of information regarding the use and the benefit of this type of pesticide. Therefore, the author researches "The Activity of Nimba Leaves (Azadirachta Indica A. Juss.) Extract Insecticide as Vegetative Pesticide On Rice Weevil (S. oryzae L.). This is based on the opinion of [11] which stated that the use of vegetative insecticide is more prospective to develop because the substance for the ingredient is available and is easy to make, therefore making it easier to be adopted by farmers and society. One of the types of chemical substance which can be used as a vegetative pesticide is azadirachtin which is produced from the plant Nimba (A. indica A. Juss.) that is accumulated on the leaves and specifically in the seed [7].

\section{Research Method}

\subsection{Place and Time of Research}

The procurement of the test insect $S$. oryzae $\mathrm{L}$. is conducted on the rice storage from the people in Sama, Pedungan, south Denpasar sub-district. The imago of $S$. oryzae L. undergoes the process of rearing in Biology Laboratory of Mathematics and Natural Science Laboratory of the University of Udayana for April to August 2017. The Nimba leaves (Azadirachta indica A. Juss.) is procured in the vicinity of the University of Udayana campus, Jimbaran, Badung district. 


\subsection{Materials and Tools}

The materials that are used in this research are rice, Nimba leaves, methanol, Sitophilus oryzae L. insect, filter paper Whatman Number 1, label paper, and gauze. The tools that are used in this research are blender, analytic scale (ohase), rotary evaporator, Bucher funnel, micropipette, Erlenmeyer, measuring glass, aluminum foil, plastic storage or storage for controlling test insect, pin, knife, wooden board, basin, rubber band, and camera.

\subsection{Working Method}

\section{Procuring Extract Material}

The extract is made from Nimba (A. indica A. Juss.) which has aged (dark green to yellow hue). The leaves are cleaned and dried for 7 days, then blended until it becomes powder. The powder of Nimba is then macerated with methanol pro analysis (PA) at the ratio (1:10) (b/v) for 72 hours, then filtered using the filter paper Whatman Number 1, therefore, it could be separated between the solvent and the dissolved substance in the forms of the filtrate. This filtrate is then evaporated using a rotary evaporator vacuum, therefore, acquiring concentrated substance like cooking oil which is called a crude extract that is assumed as thick concentration (100\%). The crude extract is then diluted using methanol pro analysis (PA) on concentration: $10 \mathrm{ppm}, 100 \mathrm{ppm}$, $1000 \mathrm{ppm}, 10000 \mathrm{ppm}, 100000 \mathrm{ppm}$, and the extract is ready to be tested to the test insect (the imago of $S$. oryzae L.), meanwhile the control test is using methanol.

\section{Procurement of Test Insect}

The rearing of rice weevil is necessary to acquire the population of test insects with similar age and to minimize the environmental factor. The rearing is conducted in 5 plastic storage (rearing box) containing 200 grams of rice and infested to 30 individual rice weevils ( $S$. oryzae L.) to each plastic storage. The storage is covered with gauze so that the air could flow and incubated for 7 days in impermeable to lightroom at room temperature $\left(28-30^{\circ} \mathrm{C}\right)$ and air humidity of $65-95 \%$ so that insect could lay the eggs on the rice, which afterward the imago will be transferred to other storage. The eggs of $S$. oryzae L. hatch and grow into imago after 25-26 days form the infestation and this imagos are the first generation (F1) of rice weevil (S. oryzae L.). The same treatment is done from F1 to obtain the second generation (F2), which is ready to be used as the test insect.

\section{Test of Contact Poison}

$500 \mu \mathrm{L}$ of crude extract of Nimba leaves are applied to each of the upper and lower surfaces of Petri dish evenly on concentration 10 ppm, 100 ppm, 1000 ppm, 10000 ppm, 100000 ppm and for the control treatment methanol pro analysis (PA) is used. The different treatment of the concentration level is repeated 4 times. After applying the extract to the Petri dish, it is left for 15 minutes to evaporate the methanol inside the filtrate. Afterward, 10 individual imagos $S$. oryzae are infested to each of the petridish without feeding it. Observations are conducted on 12 hours, 24 hours, and 48 hours after the infestation.

\section{Antifeedant Activity Test and Pesticide}

25 grams of rice wrapped in the filter plastic is dipped in the Nimba leaves (A. indica A. Juss.) extract by the assigned concentration which are 10 ppm, 100 ppm, 1000 ppm, 10000 ppm, 100000 $\mathrm{ppm}$, and 5 grams is dipped in the methanol pro analysis (PA) (as control treatment) for 1 minute. 1 gram of rice is put in each of the petridish and is opened for 15 minutes so that the methanol solvent could evaporate. The second generation (F2) of the S. oryzae L. imago is initially fasted for 48 hours, afterward about 10 individual test insects are infested to the petridish which each contains 
1 gram of rice with a repeat of each treatment 4 times. The observation is conducted at 12, 24, 36, and 48 hours after the infestation by calculating the mortality of the insects (dead insects) using the formula of:

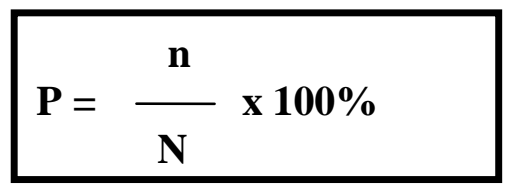

\author{
Information: \\ P: percentage of dead insects \\ $\mathrm{n}$ : number of dead insects \\ $\mathrm{N}$ : Number of used insects
}

\title{
3. Results and Discussion
}

\subsection{The Activity of Nimba Leaves Extract Contact Poison towards The Rice Weevil}

The observation result of the activity of Nimba leaves extract contact poison towards 10 individual insects $S$. oryzae L. for 48 hours after repeated application of 4 times. The data of the research showed that there is a tendency of increase in mortality of rice weevil form the increased concentration that is given up to $1000 \mathrm{ppm}$, although statistically, the result is not yet sufficient to realize a significant difference at $5 \%$ level $(\mathrm{P}<0.05)($ Table 1$)$.

Table 1

Percentage of $S$. oryzae L. deaths in the contact poison test with treatment neem leaf extract

\begin{tabular}{lllll}
\hline \multirow{2}{*}{ Treatment } & \multicolumn{4}{l}{ Percentage of test insect mortality } \\
\cline { 2 - 5 } & $\begin{array}{l}\text { 12 hours after } \\
\text { application }\end{array}$ & $\begin{array}{l}\text { 24 hours after } \\
\text { application }\end{array}$ & $\begin{array}{l}\text { 36 hours after } \\
\text { application }\end{array}$ & $\begin{array}{l}\text { 48 hours after } \\
\text { application }\end{array}$ \\
\hline Control & $0 \pm 0 \mathrm{a}$ & $0 \pm 0 \mathrm{a}$ & $6.66 \pm 0.58 \mathrm{ab}$ & $6.66 \pm 0.58 \mathrm{ab}$ \\
$10 \mathrm{ppm}$ & $3.33 \pm 0.57 \mathrm{ab}$ & $36.66 \pm 0.58 \mathrm{c}$ & $46.66 \pm 0.58 \mathrm{c}$ & $80.00 \pm 1.73 \mathrm{def}$ \\
$100 \mathrm{ppm}$ & $16.66 \pm 1.53 \mathrm{~b}$ & $40.00 \pm 0.00 \mathrm{c}$ & $66.00 \pm 0.58 \mathrm{~d}$ & $80.00 \pm 1.0 \mathrm{def}$ \\
$1000 \mathrm{ppm}$ & $50.00 \pm 1.73 \mathrm{c}$ & $76.66 \pm 0.58 \mathrm{de}$ & $83.33 \pm 0.58 \mathrm{efg}$ & $93.33 \pm 0.58 \mathrm{fg}$ \\
$10000 \mathrm{ppm}$ & $70.00 \pm 2.00 \mathrm{de}$ & $96.66 \pm 0.58 \mathrm{~g}$ & $100.00 \pm 0.00 \mathrm{~g}$ & $100.00 \pm 0.00 \mathrm{~g}$ \\
$100000 \mathrm{ppm}$ & $93.33 \pm 1.16 \mathrm{fg}$ & $96.66 \pm 0.58 \mathrm{~g}$ & $100.00 \pm 0.00 \mathrm{~g}$ & $100.00 \pm 0.00 \mathrm{~g}$ \\
\hline
\end{tabular}

Note: Numbers followed by the same letters in the same row and column show no significant difference at the $0.05 \%$ test level $(\mathrm{P}<0.05)$.

The observation towards the given treatment showed that Nimba leaves extract at a concentration of $1000 \mathrm{ppm}, 10000 \mathrm{ppm}$ and $100000 \mathrm{ppm}$ showed activity as contact poison which caused the deaths of the test insect up to $>80 \%(83.33 \%)$ at 36 hours after the treatment. At concentrations $10000 \mathrm{ppm}$ and $100000 \mathrm{ppm}$ the death has reached $100 \%$ at observation 36 hours after the treatment, meanwhile at $10 \mathrm{ppm}$ and $100 \mathrm{ppm}$ the death of the test insect has reached $80 \%$ at 48 hours after the treatment. On the control treatment using the methanol, the death of the test insect is $6.66 \%$ at 36 hours and 48 hours after the treatment (Table 1).

The statistical analysis of the amount of death of the insect at control treatment is different compared to the deaths of the insect given the treatment of Nimba leaves extract, but the deaths of the insect at $10 \mathrm{ppm}$ and $100 \mathrm{ppm}$ at 24,36, and 48 hours after treatment are yet to show the death percentage $>80 \%$. This is due to the active substance of Nimba leaves at concentration $10 \mathrm{ppm}$ and $100 \mathrm{ppm}$ is not yet capable of giving the effect that could cause the mortality to the test insect. According to [12] in [13] a substance is considered effective if the effect could kill >805 test insects. The Nimba leaves extract at concentration $1000 \mathrm{ppm}, 10000 \mathrm{ppm}$ and $100000 \mathrm{ppm}$ has the contact poison activity towards the pest $S$. oryzae L. and is most optimum as contact poison is the treatment with a concentration of $1000 \mathrm{ppm}$ at 36 hours after the treatment, meanwhile, the maximum treatment happens at concentration $10000 \mathrm{ppm}$ at 36 hours after the treatment. [14] stated that the increase of concentration is proportional to the increase of the poison material itself, 
therefore making the killing rate increase. The observation after the treatment showed that the insect went up to the gauze lid, proofing that the active substance contained in the Nimba leaves extract that covered the rice started to irritate the respiratory of $S$. oryzae due to the lack of oxygen, therefore, it went to look for some low oxygen causing the spiracles to keep opening and could irritate the insect. At the beginning of the treatment, the insect still behaves actively, however at the next moment there is some evidence of inactivity by the insect which leads to mortality.

The deaths of $S$. oryzae L. could be caused by the bioactive substance of the Bimba leaves. The extract of the leaves contains a bioactive substance which is part of the limonoid group (triterpenoid) which is known to contain pesticides which are: azadirachtin, salanin, nimbinen, and meliantriol. Azadirachtin $\left(\mathrm{C}_{35} \mathrm{H}_{44} \mathrm{O}_{16}\right)$ is a substance widely available in the Nimba plant [7]. This is in accordance to the result of the research by [15], the vegetative insecticide can cause mortality to rice weevil at day seven, with a dosage of $15 \mathrm{~g}(\mathrm{~b} / \mathrm{b}) 66 \%$ of lemongrass leaves extract (Cymbopogon citratus) and 60\% of Noni leaves (Morinda citrifolia L.). [16] stated that powder of soursop seed and srikaya are given 7 days after the treatment causing the mortality at rice weevil Sitophilus oryzae L. treatment $4 \mathrm{~g} / 200 \mathrm{~g}$ rice at the amount of $92.22 \%$ and $5 \mathrm{~g} / 200 \mathrm{~g}$ rice of $100 \%$. Azadirachtin is a substance that is quite active which is indirectly fatal to the insect but through the mechanism of an eating disorder, could hinder the growth and reproduction of insect, which is caused by the existence of antifeedant and repellent towards the $S$. oryzae. insect.

Extract of Nimba works in a way of interfering the reproduction and behavior in forms of repellent, attractant, antifeedant, interfering the growth of insect, and poisoning larva and imago, either as a pesticide or as a contact poison. The poison effect of the contact poison and pesticide is by entering the body of the insect if the insect makes contact with the pesticide, the mechanism of the active substance of vegetative pesticide is entering the body through the folding of the wings and other parts that have a sensitivity to the active substance. This is backed by the statement of [17] which stated that active pesticide substance (biopesticide) enters the body through the folding of the wings and then works inside the insect in such a way it reduces the appetite, hindering the life of an insect until it dies. Sitronela substance which is found in the Nimba leaves is a contact poison and cause dehydration therefore insect loses its liquid over and over and could cause death [17]. Moreover [18] stated that sitronela substance contains a desiccant and contact poison, therefore insect that is exposed to this poison could die of dehydration.

\subsection{Activity of Antifeedant and Nimba Leaves Pesticide towards Rice Weevil (S. oryzae L.)}

Based on statistical analysis, the antifeedant activity of neem leaf extract against $S$. oryzae L. imago at a concentration of $1000 \mathrm{ppm}$ to a concentration of $100000 \mathrm{ppm}$ showed significant differences with the control treatment. At concentrations of $10 \mathrm{ppm}$ and $100 \mathrm{ppm}$ showed no significant difference with the control. Thus, at concentrations of $10 \mathrm{ppm}$ and $100 \mathrm{ppm}$, neem leaf extracts have not been able to cause antifeedant effects on S. oryzae L. imago (Table 2).

Table 2

Pesticide activity of Nimba leaf extract against insects $S$. oryzae L. in antifeedant and stomach poison testing

\begin{tabular}{llcc}
\hline No & $\begin{array}{l}\text { Extract concentration } \\
(\mathrm{ppm})\end{array}$ & $\begin{array}{r}\text { The average weight of rice eaten } \\
\text { by S.oryzae } \mathrm{L}(\mathrm{g}) \text { for } 48 \text { hours }\end{array}$ & $\begin{array}{c}\text { The average mortality of } S . \text { oryzae } \mathrm{L} . \\
\text { imago }(\%) \text { for } 48 \text { hours }\end{array}$ \\
\hline 1 & Kontrol & $0.026 \mathrm{a}$ & $0.000 \mathrm{a}$ \\
2 & 10 & $0.025 \mathrm{a}$ & $3.33 \mathrm{a}$ \\
3 & 100 & $0.022 \mathrm{a}$ & $3.33 \mathrm{a}$ \\
4 & 1000 & $0.012 \mathrm{~b}$ & $10.00 \mathrm{a}$ \\
5 & 10000 & $0.008 \mathrm{~b}$ & $0.00 \mathrm{a}$ \\
6 & 100000 & $0.004 \mathrm{~b}$ & $0.00 \mathrm{a}$ \\
\hline
\end{tabular}

Note: Numbers followed by the same letters in the same row and column show no significant difference at the $0.05 \%$ test level $(\mathrm{P}<0.05)$. 
The data shows that the higher concentration of Nimba leaf extract given causes the amount of rice eaten by $S$. oryzae L. imago to decrease. The low feeding activity of S. oryzae L. imago in rice treated with neem leaf extract at a higher concentration is due to the amount of active substance from neem leaf extract that is increasingly on the surface of the rice which causes a stronger antifeedant effect. The results showed a correlation between the concentration of treatment (ppm) and the amount $(\mathrm{g})$ of rice eaten and the percentage (\%) mortality of rice flea. The higher the concentration of the treatment given the less amount of rice eaten.

Statistically, between the treatment at $1000 \mathrm{ppm}, 10000 \mathrm{ppm}$ and $100000 \mathrm{ppm}$ are different from the control $(\mathrm{P}<0.05)$. However, if compared with the mortality percentage of rice weevil, then the higher the given extract concentration could cause a high rate of rice weevil mortality until up to certain level concentration and there is no more mortality after the dosage is increased. This shows that the Nimba leaves extract contains a substance that could induce antifeedant towards the test insect. According to [19], Nimba contains azadirachtin which is the best substance among different vegetative pesticides, because it could act as antifeedant, hindering the growth and the reproduction of insects pest. The result of the research by [20] could strengthen the result of this research by stating that Nimba is effective to control during application at insect repellent, the extract could reduce mosquito bite up to $84.5 \%-85 \%$. The Nimba leaves extract is effective to control Plutella xylostella L. larva pest to cabbage plant up to 85-88\% on the field [21]. [22] reported that azadirachtin contains antifeedant, when insect larva swallows azadirachtin, the growth is interfered with due to the blockage of biosynthetic hormone such as ecdysteroids.

Azadirachtin is indirectly fatal to insects, but through the mechanism of the eating disorder, interfering with the growth and the reproduction of the insect. Salanin works as food interference to the insect. This is by the statement by the [23] and [24] that there is numerous sensitive organism towards Nimba Extract, one of which is insect and the impact includes the incapability of digesting food properly. Seed and leaves of Nimba could be used as insecticide, bactericide, fungicide, akarisida, nematicide, and viricide, active substances which are contained mainly in the seed which is Azadirachtin, meliantriol, salanin, and nimbin [25]. Azadirachtin which is inhaled by insects could cause interference in the neuron system [26]. According to those statements, azadirachtin acts to reduce the activity of the insect gradually, for example reducing the capability of the insect in digesting food. This shows that the active chemical substance in Nimba leaves extract is more antifeedant (reducing appetite) rather than a pesticide, because the higher the given concentration the higher the active substance from the extract accumulated on the substrate (rice) which is causing the antifeedant to become stronger as well, therefore the less the eaten rice the less the death of the rice weevil as well.

\section{Conclusion}

Based on the description above, the conclusion is the crude extract of Nimba leaves at an optimum concentration of $1000 \mathrm{ppm}$ and a maximum of $10000 \mathrm{ppm}$, observation period at 36 hours after application, is leaning to a more contact poison towards the Sitophilus oryzae L. pest. The extract of Nimba leaves does not act as pesticide towards the Sitophilus oryzae L. pest and acts as antifeedant (reducing appetite) towards Sitophilus oryzae L. pest at an optimum concentration of 1000 at observation time 48 hours after application.

\section{References}

[1] Hendrival \& Mayasari E. (2017). Kerentanan dan Kerusakan Beras Terhadap Serangan Hama Pascapanen Sitophilus Zeamais L. (Coleoptera: Curculionidae). Jurnal Agr. 4(2). 
[2] Anggara A W \& Sudarmaji (2008). Hama Pascapanen padi dan pengendaliannya. Di dalam: Darajat A A, Setyono A, Makarim A K \& Hasanuddin A. (eds.). Padi: inovasi Teknologi Produksi. Jakarta: Balai Besar Penelitian Tanaman Padi. LIPI Press : 441-472.

[3] Yos W H. (2016). Uji Ketahanan Beberapa Jenis Beras (Oryza Sativa) Terhadap Hama Kumbang Bubuk Beras (Sitophilus Oryzae) Agrovigor. 9 (2).

[4] Lopulalan C G C. (2010). Analisa ketahanan beberapa varietas padi terhadap serangan hama gudang (Sitophilus zeamais Motschulsky). Jurnal Budidaya Pertanian. 6 (1): 11-16.

[5] Hendrival \& Melinda L. (2017). Pengaruh Kepadatan Populasi Sitophilus oryzae (L.) terhadap Pertumbuhan Populasi dan Kerusakan Beras. Biospecies. 10 (1) : 17 - 24.

[6] Setiawan D. (2010). Kajian Daya Insektisida Ekstrak Daun Nimba (Azadirachta indica A. Juss) terhadap Perkembangan Serangga Hama Gudang Sitophilus oryzae Linn. Jurusan Biologi FMIPA Universitas Sriwijaya. Sumatera Selatan. Jurnal Penelitian Sains. Edisi Khusus Juni (D) 10: 06-12

[7] Debashri M \& Tamal M (2012). A Review on efficacy of Azadirachta indica A. Juss based biopesticides: An Indian perspective. Research Journal of Recent Sciences. 1(3) : 94-99.

[8] Akpodiete O N, Lale N E S, Umeozor O C \& Zakka U. (2015) Role of physical characteristics of the seed on the stability of resistance of maize varieties to maize weevil (Sitophilus zeamais Motschulsky). Journal of Environmental Science, Toxicology, and Food Technology 9(2): 60-66.

[9] Throne J E \& Eubanks M W. (2015). Resistance of tripsacorn-introgressedmaize lines to Sitophilus zeamais. Journal of Stored Products Research 64(Part A):62-64.

[10] Manaf S, Kusmini, \& Helmiyati E. (2005). Evaluasi Daya Repelensi daun Nimba (Azadirachta indica A. Juss) terhadap Hama Gudang Sitophilus oryzae L. (Coleoptera: Curculionidae). Jurnal Gradien. 1(1): 23-29.

[11] Babarinde S A, Sosina A \& Oyeyiola E I. (2008). Susceptibility of the selected crops in storage to Sitophilus zeamais Motschulsky in Southwestern Niger. J. Plant Prot. Res. 48(4): 541-550.

[12] Mumford J D \& Norton G A. (1984). Economics of decision making in pest management. Annual Review of Entomology. 29: 157-174.

[13] Suanda I W. (2002). Aktivitas Insektisida Ekstrak daun Brotowali (Tinospora crispa L.) sebagai Insektisida Nabati untuk Mengendalikan Larva Plutella xylostella pada Tanaman Kubis (Brassica oleracea var. capitate. Tesis. Program Studi Bioteknologi Pertanian Program Pascasarjana Universitas Udayana.

[14] Purba S. (2007). Uji Efektivitas Ekstrak Daun Mengkudu (Morindacitrifolia) terhadap Plutellaxylostella L. (Lepidoptera : Plutellidae) di Laboratorium. Skripsi. Universitas Sumatera Utara. Medan : 29-35.

[15] Isnaini M, Elfira R P \& Wiridianti S. (2015). Pengujian Beberapa Jenis Insektisida Nabati terhadap Kutu Beras (Sitophylus oryzae L.). Prodi Pendidikan Biologi, Fakultas Tarbiyah dan Keguruan, UIN Raden Fatah Palembang. Jurnal Biota. 1(1): 1-8.

[16] Lihawa Z \& Toana M H. (2017). Pengaruh Konsentrasi Serbuk Majemuk Biji Sarikaya dan Biji Sirsak terhadap Mortalitas Kumbang Beras Sitophilus oryzae L. (Coleoptera: Curculionidae) di Penyimpanan. Program Studi Agroteknologi. Fakultas Pertanian. Universitas Tadulako. Palu. e-J. Agrotekbis 5 (2): 190 - 195.

[17] Setiawati W R, Murtiningsih N, Gunaeni \& Rubiati T. (2008). Tumbuhan Bahan Pestisida Nabati dan cara Pembuatannya untuk Pengendalian Organisma Pengganggu Tumbuhan (OPT). Balai Penelitian Sayuran. Balitbang Pertanian.

[18] Saenong M S. (2016). Tumbuhan Indonesia Potensial sebagai Insektisida Nabati untuk Mengendalikan Hama Kumbang Bubuk Jagung (Sitophilus spp.). Balai Penelitian Tanaman Serealia. Jurnal Litbang Pertanian. 35(3): 131-142.

[19] Singhal N \& Monika S. (1998). Neem and Environment. Word Neem. 14. New Delhi: 22-37.

[20] Boadu K O, Tulashie S K, Anang M A \& Kpan J D. (2011). Production of natural insecticide from Neem leaves (Azadirachta indica). Asian Journal of Plant Science and Research. 1(4): 33-38

[21] Suanda I W \& Kristiana Y V (2004). Optimalisasi Aktivitas Senyawa Bioaktif dari Ekstrak Daun Nimba (Azadirachta indica A. Juss.) pada Hama Tanaman Kubis (Plutella xylostella). Hasil Penelitian Jurusan Biologi FMIPA Universitas Udayana: Jimbaran-Badung.

[22] Lee KY. Lynn O M, Song W G, Shim J K \& Kim J E. (2010). Effects of Azadirachtin and Neembased Formulations for the Control of Sweet potato Whitefly and Root-knot Nematode. J. Korean Soc. Appl. Biol. Chem. 53(5): 598-604.

[23] National Research Council. (1992). Neem. A Tree for Solving Global Problem. Dalam: Azadirachta indica: One Tree's Arsenal Against Pests. National Academy Press. Washington, D.C: 1-3.

[24] Strang's. (2000). The Effect of Azadirachtin. Available at: http://www.gla.ac.uk/ibls/BMB/rhcs/resint/ html. Opened: 01-03-2003 
The Activity of Nimba Leaves (Azadirachta Indica A. Juss.) Extract Insecticide as Vegetative Pesticide on Rice Weevil (Sitophilus Oryzae L.) (Coleoptera: Curculionidae)

[25] BPPT. (2007). Teknologi Budidaya Tanaman Pangan. http//www.iptek.net.id/ind/teknologi-pangan/ index.php id $=244$.

[26] Bomford (2000). Neem As An Antifeedant. Available at:http://72.14.235.104/search?q= cache: 0MUN d7mGyvol:www.Sfu.ca/bisc/bisc842/michael/web_page/antifeed.htm+antifeedant+azadirachtin\&hl=i $\mathrm{d} \& \mathrm{gl}=\mathrm{id} \& \mathrm{ct}=\mathrm{clnk} \& \mathrm{~cd}=6$ Opened: $20-10-2006$. 